\title{
Dolomitic limestone as an alkalizing agent for treating cassava starch wastewater in an anaerobic reactor ${ }^{1}$
}

\author{
Denise Palma ${ }^{2 *}$, Julia Piechontcoski Fernandes ${ }^{3}$, Marney Pascoli Cereda ${ }^{4}$, Simone Damasceno Gomes ${ }^{2}$
}

\author{
$10.1590 / 0034-737 X 201865050002$
}

\begin{abstract}
Cassava processing wastewater has a low Volatile Acidity/Total Alkalinity ratio, low buffering capacity and became quickly acidified. In this trial, dolomitic limestone was used as an alkalizing agent in an anaerobic reactor to treat cassava starch wastewater. The dolomitic limestone contained $27 \% \mathrm{CaO}$ and $23 \% \mathrm{MgO}$ and granulometry between 24.5 and $38.1 \mathrm{~mm}$. The average Chemical Oxygen Demand of the wastewater was $13331.30 \mathrm{mgO}_{2} \mathrm{~L}^{-1}$, the organic loading rates (OLR) ranged from 1.23 to $16.43 \mathrm{gCOD} \mathrm{L}^{-1} \mathrm{~d}^{-1}$ and the hydraulic retention times ranged from 10.00 to 0.80 days. The results showed that the calcium concentrations increased in the reactor effluent and the magnesium concentrations decreased as the organic loading rates increased. $\mathrm{Ca}^{2+}$ and $\mathrm{Mg}^{2+}$ concentrations were approximately 5,000 and 5.05 times greater in the sludge than in the inoculum, respectively. The average $\mathrm{pH}$, Total alcalinity, Volatile Acidity and Volatile Acidity/ Total alcalinity values were $6.69,882.54 \mathrm{mgCaCO}_{3} \mathrm{~L}^{-1}, 221.55 \mathrm{mgCH}_{3} \mathrm{COOH} \mathrm{L}^{-1}$ and 0.22 , respectively. The loss of limestone mass corresponded to only $2.51 \%$ of the initial mass, after 134 days of anaerobic reactor operation. Finally, it was concluded that the limestone effectively controlled acidification through the alkalinity increased in the system.
\end{abstract}

Keywords: acidity; alkalinity; calcium; magnesium.

\section{RESUMO}

\section{Calcário dolomítico como agente alcalinizante para tratamento de água residuária de fecularia em reator anaeróbio}

A água residuária do processamento da mandioca tem baixa relação Acidez Volátil/Alcalinidade Total, baixa capacidade de tamponamento e torna-se rapidamente acidificada. Neste ensaio, calcário dolomítico foi usado como um agente alcalinizante em um reator anaeróbio para tratar a água residuária de fecularia. O calcário dolomítico continha $27 \%$ de $\mathrm{CaO}$ e $23 \% \mathrm{MgO}$ e granulometria entre 24,5 e 38,1 mm. A Demanda Química de Oxigênio média do efluente era $13.331,30 \mathrm{mgO}_{2} \mathrm{~L}^{-1}$, as taxas de cargas orgânicas variaram de 1,23 a $16,43 \mathrm{gDQO} \mathrm{L}^{-1} \mathrm{~d}^{-1}$ e o tempo de retenção hidráulica variou de 10,00 a 0,80 dias. Os resultados mostraram que concentração de cálcio aumentou no efluente do reator e as

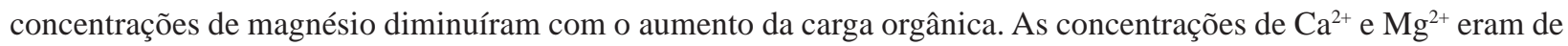
aproximadamente 5,000 e 5,05 vezes maiores no lodo do que no inóculo, respectivamente. $\mathrm{O} \mathrm{pH}$, alcalinidade total, acidez volátil e acidez volátil/alcalinidade total foram 6,69, 882,54 $\mathrm{mgCaCO}_{3} \mathrm{~L}^{-1}, 221,55 \mathrm{mgCH}_{3} \mathrm{COOH} \mathrm{L}^{-1} \mathrm{e}$ 0,22, respectivamente. A perda de massa do calcário correspondeu a apenas 2,51\% da massa inicial, após 134 dias de operação do reator anaeróbio. Finalmente, concluiu-se que o calcário controlada eficazmente acidificação através do incremento de alcalinidade no sistema.

Palavras-chave: acidez; alcalinidade; cálcio; magnésio.

\footnotetext{
Submitted on November $2^{\text {nd }}, 2016$ and accepted on September $9^{\text {th }}, 2018$.

${ }^{1}$ This work is part of the first author Master's Dissertation.

2 Universidade Estadual do Oeste do Paraná, Centro de Ciências Exatas e Tecnológicas, Programa de Pós-graduação em Engenharia Agrícola, Cascavel, Paraná, Brazil. palmadenise@yahoo.com.br; simone.gomes@unioeste.br

${ }^{3}$ Universidade Estadual do Oeste do Paraná, Centro de Engenharias e Ciências Exatas, Toledo, Paraná, Brazil. piechontcoskiju@hotmail.com

${ }^{4}$ Universidade Católica Dom Bosco, Centro de Tecnologia para o Agronegócio, Campo Grande, Mato Grosso do Sul, Brazil. cereda@ucdb.br

*Corresponding author: palmadenise@yahoo.com.br
} 


\section{INTRODUCTION}

In Brazil, starch industries generate $2.6 \mathrm{~m}^{3}$ of root wash water and $3.6 \mathrm{~m}^{3}$ of water of starch extraction per ton of processed manioc (Pinto \& Cabello, 2011). The physicochemical characterization of the wastewater of cassava industry may vary depending on the variety of the roots and starch extraction process (Camili \& Cabello, 2008). Starch production generates wastewater with organic matter concentrations of up to $15000 \mathrm{mg} \mathrm{L}^{-1}$ (Kuczman et al., 2011). The $\mathrm{pH}$ of this wastewater varies from approximately 4.0 (Duarte et al., 2012; Sun et al., 2012) to 6.5 (Cassoni \& Cereda, 2011).

Cassava processing wastewater requires treatment because it is a pollutant. Anaerobic reactors are able to tolerate high organic loading and offer the possibility of operating with high solids retention times (Aquino \& Chernicharo, 2005). In anaerobic treatment, $\mathrm{pH}$ stability is one of the most important factors. The optimum $\mathrm{pH}$ range for the growth of methanogenic archaea is between 6.6 and 7.6; however, methane $\left(\mathrm{CH}_{4}\right)$ formation may occur across the wider $\mathrm{pH}$ range of 6.0 to 8.0. In addition, $\mathrm{pH}$ values below 6.0 and above 8.3 must be avoided in order to prevent the inhibition of methanogenic Achaea (Chernicharo, 2007).

Dolomitic limestones mainly composed of $\mathrm{Ca}$ and $\mathrm{Mg}$ oxides were analysed previously by Brazilian researchers to treat wastewater from the cassava flour (Ribas \& Cereda, 2004), vinasse (Oliveira Júnior et al., 2012) and cassava starch industries (Palma et al., 2018). The obtained results have indicated that $\mathrm{Ca}$ and $\mathrm{Mg}$ oxides serve as neutralizing agents and as fixed beds, mainly in rural areas. The authors observed bicarbonate alkalinity directly through the limestone surface wear; thus, $\mathrm{CaCO}_{3}$ availability was increased slowly to avoid sudden changes in $\mathrm{pH}$ and eliminate the need of devices for dosing powder and liquid alkalizing agents. Thus, because alkalinity must be maintained during cassava processing wastewater treatment in anaerobic reactors, this paper aims to analyse the efficiency of dolomitic limestone as an alkalizing agent.

\section{MATERIALAND METHODS}

The horizontal tubular reactor used in this study was made of polyvinyl chloride and $90 \mathrm{~cm}$ long and had a diameter of $15 \mathrm{~cm}$, a total volume of $15.9 \mathrm{~L}$ and a useable volume of $7.95 \mathrm{~L}$. Two floating dome gasometers were connected to the reactor to determine biogas production. The larger diameter tube of the gasometer $(20 \mathrm{~cm})$ was capped at its base and filled with $\mathrm{H}_{2} \mathrm{O}$ to form a water seal. The smaller diameter tube $(15 \mathrm{~cm})$ was capped at its upper end and had a biogas removal valve. The reactor was supplied daily, and cassava proceeding wastewater volu- me was distributed sequentially by means of a peristaltic pump coupled to a timer (Figure 1).

The wastewater was obtained in a cassava starch industry (Toledo, PR, Brazil). After the samples were selected for characterization, the wastewater was stored at $-4{ }^{\circ} \mathrm{C}$ and thawed at room temperature before using it to feed the reactor. The sludge used in the inoculum was collected from a pilot-scale digester used for treating starch wastewater from the same starch industry where wastewater was collected for this experiment. The inoculum consisted of $30 \%$ sludge, $10 \%$ starch extraction wastewater, and $60 \%$ distilled water, which was calculated based on the useable reactor volume. Table 1 shows the averaged inoculum characteristics and the characteristics of the five batches of cassava processing wastewater used in the trial.

Dolomitic limestone was used as the support material and contained $27.33 \% \mathrm{CaO}$ and $22.97 \% \mathrm{MgO}$ according to the technical reports of the supplier company. The rocks were standardized according to their granulometry. In this trial, limestone that passed through an ABNT 11/2" sieve and was retained on an ABNT 1" sieve (Brazilian Association of Technical Standards) was used. Thus, the limestone was between 24.5 and $38.1 \mathrm{~mm}$ in diameter. The rocks were then dried in an oven $\left(60^{\circ} \mathrm{C}\right.$ to $\left.24 \mathrm{~h}\right)$, cooled to room temperature in a desiccator and weighed. The rocks were divided into 6 sets with weights from 1256.71 to $1292.33 \mathrm{~g}$. Each set was placed in a plastic raffia net (Figure 1). The nets were placed along the reactor profile to account for $50 \%$ of its useful volume (Ribas \& Barana, 2003).

The reactor was operated using mesophilic temperature conditions $\left(27^{\circ} \mathrm{C}\right)$ that were maintained by a water bath system during the $140-\mathrm{d}$ trial. Cassava processing wastewater COD served as the basis for determining the following organic loading rates: 1.23, 1.54, 1.84, 2.45, 3.40, 4.96, 6.01, 8.11, 10.14, 12.39, 14.79 and $16.43 \mathrm{~g} \mathrm{COD} \mathrm{L}^{-1} \mathrm{~d}^{-1}$ with respective hydraulic retention times of 10.00, 7.99, $6.65,5.00,4.42,1.69,1.39,2.21,1.77,1.45,0.88$ and 0.80 days. At the OLR transition from 3.4 to $4.96 \mathrm{gCOD} \mathrm{L}^{-1} \mathrm{~d}^{-1}$ (TDH 4.42 and $1.69 \mathrm{~d}$, respectively), the reactor affluent flow was increased to a value 6 times higher than that used in OLR above. This procedure had as objective to evaluate the performance of the overloaded reactor. However, there was drag of solids from the reactor, with loss of biomass in the effluent during the organic loading rates of 4.96 and $6.01 \mathrm{gCOD} \mathrm{L}^{-1} \mathrm{~d}^{-1}$. Thus, it was necessary to reduce the flow rate to a value that did not result in biomass loading. This explains the TDH 2.21, 1.17 and 1.45 days, higher than the two immediately preceding.

The organic loading rates was always increased after the reactor stabilized following the previous organic loading rates increase, which was considered to occur 
when the $\mathrm{pH}$ remained unchanged for at least three days, the AV/AT ratio was below 0.5 , and constant biogas production occurred.

In each organic loading rate (OLR), after the $\mathrm{pH}$ values stability was verified, samples of the reactor effluent were collected during three consecutive days for the chemical analyzes: $\mathrm{Ca}$ and $\mathrm{Mg}$ concentrations, $\mathrm{pH}$, partial alkalinity (PA), intermediate alkalinity (IA), total alkalinity (TA), volatile acidity (VA), volatile acidity/total alkalinity ratio (VA/TA), volatile fatty acids (VFA) and chemical oxygen demand (COD), according to the methodologies described in Table 1. For volatile organic acid content analysis, the samples were diluted 2.5 times, acidified with $400 \mu \mathrm{L}$ of a $2 \mathrm{M}$ sulfuric acid solution and analysed using High-Performance Liquid Chromatography as follows: using an Allure Organic Acids column (250 mm x $4.6 \mathrm{~mm}$ ), a UV detector with a wavelength of $208 \mathrm{~nm}$, a temperature of $47^{\circ} \mathrm{C}$, a flow rate of $0.6 \mathrm{~mL} \mathrm{~min} \mathrm{~m}^{-1}$ and $90 \%$ mobile phase A (formed by water with $0.05 \%$ trifluoroacetic acid) and $10 \%$ mobile phase B (formed by acetonitrile with $0.025 \%$ trifluoroacetic acid). The detection times of lactic acid, acetic acid, propionic acid and butyric acid were 5.7, 6.9, 11.4 and $24.7 \mathrm{~min}$, and the total detection time was $30 \mathrm{~min}$.

At the end of the trial, the top part of the reactor was opened and the liquid above the sludge was removed. The limestone bags were carefully removed and washed with distilled water to remove any adhered sludge. The limestone dry weight lost due to surface corrosion was determined. The bottom sludge samples were collected at three points along the length of the reactor $(15,45$ and 75 $\mathrm{cm}$ ) for determination of calcium and magnesium concentration.

All analyzes were performed in triplicate and the data were analyzed using the statistical software Minitab Version 16.0. The parameters that showed variance homoscedasticity and presented a significant p-value were subjected to Tukey's comparison test at a $5 \%$ significance level.

\section{RESULTS}

During the test, the calcium concentration in the reactor effluent was higher than the concentration of this element in the reactor affluent, while the magnesium concentration was lower in the effluent than in the reactor affluent. The resulting $\mathrm{Ca}^{2+}$ and $\mathrm{Mg}^{2+}$ concentrations are presented in Table 2 for the cassava processing wastewater and treated effluent for each applied organic loading rates. The $\mathrm{Ca}^{2+}$ content significantly increased from organic loading rate $1.54 \mathrm{gCOD} \mathrm{L}^{-1} \mathrm{~d}^{-1}$ and remained constant until organic loading rate of $8.11 \mathrm{gCOD} \mathrm{L}^{-1} \mathrm{~d}^{-1}$ was reached, which corresponded with the point at which
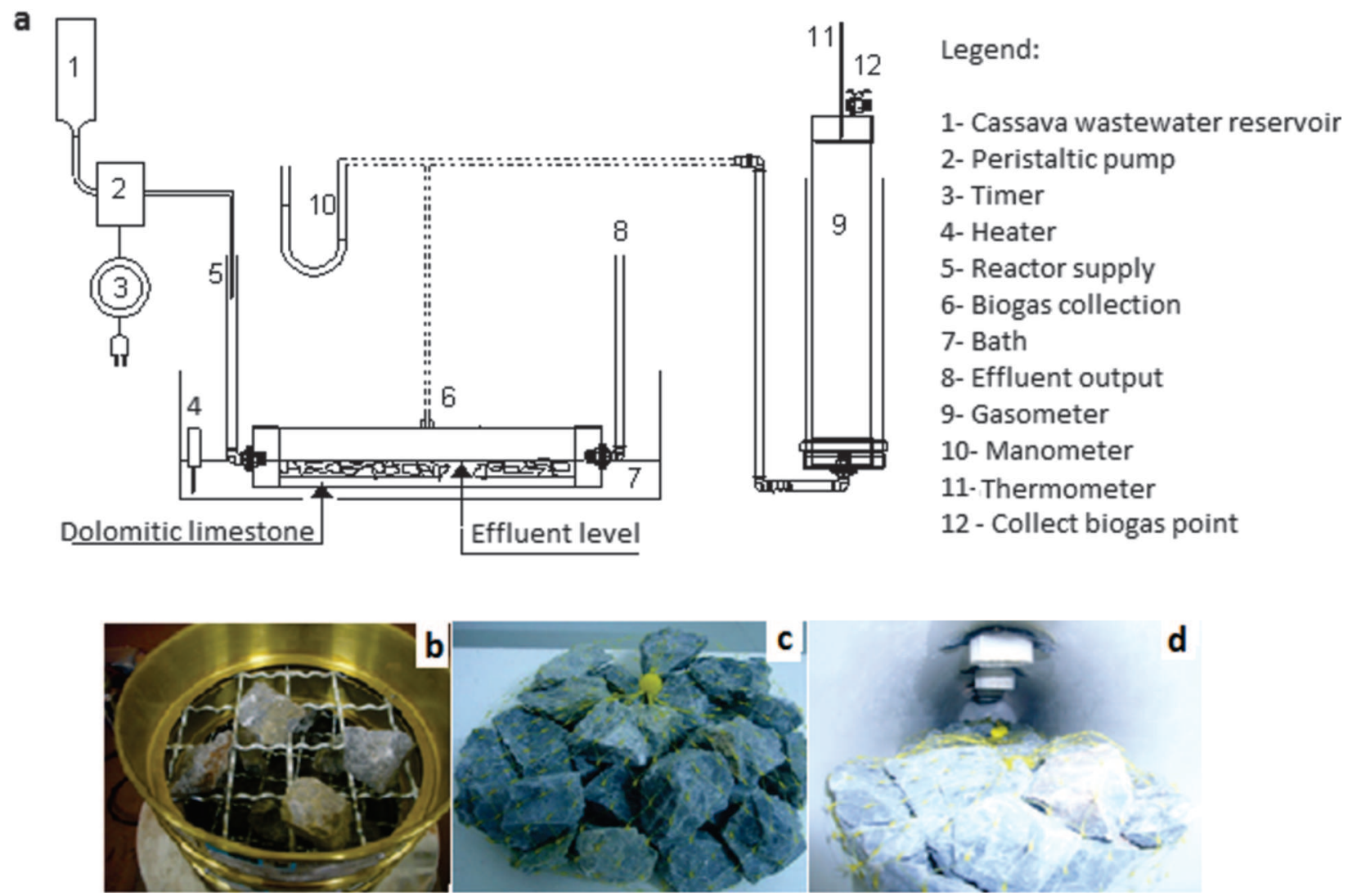

Figure 1: Diagram of the anaerobic treatment system: (a) experimental apparatus; (b) standardization process of limestone; (c) packaging of rocks in bags and (d) limestone arranged into the reactor. 
the Ca content of the reactor effluent began to decrease. The greatest $\mathrm{Mg}^{2+}$ removal occurred at a loading rate of 14.79 $\mathrm{gCOD} \mathrm{L}^{-1} \mathrm{~d}^{-1}$.

The percentages of dry mass removed for the six sets of limestone based on their dry weights before the trial range from 2,25 to $2,65 \%$. On average, the total weight decreased by $32 \mathrm{~g}$, corresponding to an average total weight decrease of $2.51 \%$. This result indicates the limestone wear, with consequent calcium and magnesium release, that resulted from buffering the solution and maintaining the stability of the system. The $\mathrm{Mg}^{2+}$ concentration in the reactor sludge at the end of this trial was 5.05 times greater than the $\mathrm{Mg}^{2+}$ concentration in the inoculum, and the $\mathrm{Ca}^{2+}$ concentration was approximately 5000 times greater than the $\mathrm{Mg}^{2+}$ concentration in the inoculum (Table 3). This result seems to indicate that magnesium ions are derived from limestone dissolution.

However, $\mathrm{Ca}^{2+}$ and $\mathrm{Mg}^{2+}$ ions may be toxic to bacteria. $\mathrm{Ca}^{2+}$ concentrations of up to $200 \mathrm{mg} \mathrm{L}^{-1}$, between 2,500 and 4,500 $\mathrm{mg} \mathrm{L}^{-1}$, and above $8,000 \mathrm{mg} \mathrm{L}^{-1}$ stimulate, moderately inhibit, and strongly inhibit bacterial activity, respectively. While, $\mathrm{Mg}^{2+}$ concentrations of up to $150 \mathrm{mg}$ $\mathrm{L}^{-1}$ stimulate bacterial activity, $\mathrm{Mg}^{2+}$ concentrations between 1,000 and $1,500 \mathrm{mg} \mathrm{L}^{-1}$ moderately inhibit bacterial activity and $\mathrm{Mg}^{2+}$ concentrations above $3,000 \mathrm{mg} \mathrm{L}^{-1}$ strongly inhibit bacterial activity (Chernicharo, 2007). In this trial, the results obtained indicated that the release of

Table 1: Compositional characterization of the cassava processing wastewater (CPW) used in the experiments

\begin{tabular}{|c|c|c|c|}
\hline Parameter & Reference & Inoculum & CPW \\
\hline $\mathrm{COD}\left(\mathrm{mgO}_{2} \mathrm{~L}^{-1}\right)$ & APHA, 2005-5220D & $23,720.95$ & $13,331.30$ \\
\hline $\mathrm{pH}(-)$ & APHA, 2005-4500A & 6.91 & 5.37 \\
\hline $\mathrm{EC}\left(\mathrm{dS} \mathrm{m} \mathrm{m}^{-1}\right)$ & APHA, 2005-2510B & 0.61 & 0.58 \\
\hline $\mathrm{PA}\left(\mathrm{mgCaCO}_{3} \mathrm{~L}^{-1}\right)$ & Chernicharo, 2007 & 356.67 & 18.64 \\
\hline $\mathrm{MA}\left(\mathrm{mgCaCO}_{3} \mathrm{~L}^{-1}\right)$ & Chernicharo, 2007 & 50.00 & 147.56 \\
\hline $\mathrm{TA}\left(\mathrm{mgCaCO}_{3} \mathrm{~L}^{-1}\right)$ & Chernicharo, 2007 & 406.67 & 226.20 \\
\hline $\mathrm{VA}\left(\mathrm{mgCH}_{3} \mathrm{COOH} \mathrm{L}^{-1}\right)$ & Chernicharo, 2007 & 60.00 & 621.60 \\
\hline $\mathrm{VA} / \mathrm{TA}(-)$ & - & 0.48 & 1.68 \\
\hline $\mathrm{TS}\left(\mathrm{mg} \mathrm{L}^{-1}\right)$ & APHA, 1998-2540 B & $16,619.33$ & $8,292.58$ \\
\hline TFS $\left(\mathrm{mg} \mathrm{L}^{-1}\right)$ & APHA, $1998-2540 \mathrm{E}$ & $9,702.00$ & $1,432.88$ \\
\hline $\operatorname{TVS}\left(\mathrm{mg} \mathrm{L}^{-1}\right)$ & APHA, 1998-2540 E & $6,917.33$ & $6,859.69$ \\
\hline Calcium $\left(\mathrm{mg} \mathrm{L}^{-1}\right)$ & APHA, 2005-3111A & 0.17 & 6.94 \\
\hline Magnesium (mg L $\left.{ }^{-1}\right)$ & APHA, 2005-3111A & 124.55 & 151.48 \\
\hline Lactic acid $\left(\mathrm{mg} \mathrm{L}^{-1}\right)$ & APHA, 2005-5560 B & 131.64 & 948.46 \\
\hline Acetic acid $\left(\mathrm{mg} \mathrm{L}^{-1}\right)$ & APHA, 2005-5560 B & 392.68 & 533.92 \\
\hline Propionic acid $\left(\mathrm{mg} \mathrm{L}^{-1}\right)$ & APHA, 2005-5560 B & 888.20 & nd \\
\hline Butiric acid $\left(\mathrm{mg} \mathrm{L}^{-1}\right)$ & APHA, 2005-5560 B & 180.06 & 1893.07 \\
\hline
\end{tabular}

Legend: COD - Chemical Oxygen Demand; EC - Electrical conductivity; PA - Partial alkalinity; IA - Intermediate alkalinity; TA - Total alkalinity; VA - Volatile acidity; VA/TA - Volatile acidity/Total alkalinity; TS - Total solids; TFS - Total fixed solids and TVS - Total volatile solids.

Table 2: Impact of organic loading rate (OLR) on calcium and magnesium concentrations and their percent changes after treatment of cassava wastewater in an anaerobic reactor containing dolomitic limestone

\begin{tabular}{|c|c|c|c|c|}
\hline $\operatorname{OLR}\left(\operatorname{gCOD~L} \mathbf{L}^{-1} \mathbf{d}^{-1}\right)$ & $\mathrm{Ca}^{2+}\left(\mathrm{mg} \mathrm{L}^{-1}\right)$ & $\mathrm{Ca}^{2+}{ }_{\text {increase }}(\%)$ & $\operatorname{Mg}^{2+}\left(\mathrm{mg} \mathrm{L}^{-1}\right)$ & $\mathrm{Mg}^{2+}$ remotion $(\%)$ \\
\hline 1.23 & $11.55 \mathrm{a}$ & 34 & $119.87 \mathrm{def}$ & $23.26 \mathrm{ab}$ \\
\hline 1.54 & $13.53 \mathrm{a}$ & 57 & $117.86 \mathrm{cdef}$ & $24.55 \mathrm{ab}$ \\
\hline 1.84 & $607.60 \mathrm{e}$ & 7434 & 130.78 ef & $13.66 \mathrm{a}$ \\
\hline 2.45 & $595.70 \mathrm{e}$ & 7286 & 106.07 bcde & $5.98 \mathrm{a}$ \\
\hline 3.40 & $557.70 \mathrm{de}$ & 6847 & 142.95 ef & $5.57 \mathrm{a}$ \\
\hline 4.96 & $568.20 \mathrm{de}$ & 7015 & 138.62 ef & $12.67 \mathrm{a}$ \\
\hline 6.01 & $573.10 \mathrm{de}$ & 15551 & 142.40 ef & $5.03 \mathrm{a}$ \\
\hline 8.11 & $574.07 \mathrm{de}$ & 23702 & $145.70 \mathrm{f}$ & $6.65 \mathrm{a}$ \\
\hline 10.14 & $450.10 \mathrm{~cd}$ & 18562 & $87.87 \mathrm{abcd}$ & $37.57 \mathrm{ab}$ \\
\hline 12.39 & $361.69 \mathrm{c}$ & 14896 & $80.30 \mathrm{abc}$ & $42.95 \mathrm{bcd}$ \\
\hline 14.79 & $201.30 \mathrm{~b}$ & 2552 & $64.42 \mathrm{a}$ & $61.40 \mathrm{~d}$ \\
\hline 16.43 & $332.45 \mathrm{c}$ & 4281 & $75.37 \mathrm{ab}$ & $48.71 \mathrm{~cd}$ \\
\hline
\end{tabular}

Values followed by the same letter in each column are statistically equal at a $95 \%$ confidence level. 
$\mathrm{Ca}^{2+}$ and $\mathrm{Mg}^{2+}$ from limestone did not inhibit the anaerobic sludge at the studied conditions, since the organic matter removal remained high (Table 6).

Ribas et al. (2010) obtained $\mathrm{Ca}^{2+}$ and $\mathrm{Mg}^{2+}$ concentrations of 2,220 and 2,170 $\mathrm{mg} \mathrm{L}^{-1}$, respectively, in acidogenic reactor effluent for cassava flour wastewater treatment containing dolomitic limestone. Compared to

Table 3: Averages of calcium and magnesium concentrations in the reactor sludge at the end of the operation

\begin{tabular}{lcc}
\hline Sample & calcium $\left(\mathbf{m g ~ L}^{-\mathbf{1}}\right)$ & magnesium $\left(\mathbf{m g ~ L}^{-1}\right)$ \\
\hline Inoculum & 0.17 & 124.55 \\
Sludge point A & 601.98 & 482.69 \\
Sludge point B & 735.53 & 548.02 \\
Sludge point C & 424.34 & 506.79 \\
\hline
\end{tabular}

Table 4: Impact of organic loading rate (OLR) on $\mathrm{pH}$ and ratio volatile acidity/total alkalinity and their changes after treatment of cassava wastewater in an anaerobic reactor containing dolomitic limestone

\begin{tabular}{lcc}
\hline OLR $\left(\mathbf{g C O D ~ L}^{-\mathbf{1}} \mathbf{d}^{-1}\right)$ & $\mathbf{p H}(-)$ & $\begin{array}{c}\text { Volatile acidity/ } \\
\text { Total alkalinity(-) }\end{array}$ \\
\hline 1.23 & $6.72 \mathrm{a}$ & $0.43 \mathrm{ab}$ \\
1.54 & $6.87 \mathrm{a}$ & $0.14 \mathrm{ab}$ \\
1.84 & $6.63 \mathrm{a}$ & $0.12 \mathrm{ab}$ \\
2.45 & $6.52 \mathrm{a}$ & $0.09 \mathrm{ab}$ \\
3.40 & $6.60 \mathrm{a}$ & $0.08 \mathrm{a}$ \\
4.96 & $6.59 \mathrm{a}$ & $0.22 \mathrm{ab}$ \\
6.01 & $6.87 \mathrm{a}$ & $0.16 \mathrm{ab}$ \\
8.11 & $6.77 \mathrm{a}$ & $0.13 \mathrm{ab}$ \\
10.14 & $6.55 \mathrm{a}$ & $0.24 \mathrm{ab}$ \\
12.39 & $6.71 \mathrm{a}$ & $0.29 \mathrm{ab}$ \\
14.79 & $6.80 \mathrm{a}$ & $0.24 \mathrm{ab}$ \\
16.43 & $6.66 \mathrm{a}$ & $0.49 \mathrm{~b}$ \\
\hline
\end{tabular}

Values followed by the same letter in each column are statistically equal at a $95 \%$ confidence level. the study by Ribas et al. (2010), the present work presents lower calcium and magnesium concentrations. However, said concentrations appear to have been adequate adequate for maintaining stable $\mathrm{pH}$ and VA/ AT ratios. The efficiency of anaerobic digestion depends on the operational conditions of the process (Pereira et al., 2009). The $\mathrm{pH}$ values in the reactor effluent may be considered adequate for methanogenic bacteria activity and can produce $\mathrm{CH}_{4}$ in the range of 6.0 to 8.0 (Chernicharo, 2007). The VA/TA ratio relates to stability of the anaerobic digestion system, and must remain below 0.5 (Silva, 1977).

The $\mathrm{pH}$ values reactor effluent ranged from 6.52 to 6.87 throughout the trial, without statistical different between treatments. The average effluent $\mathrm{pH}$ (6.69) represented an increase of 1.3 times relative to the average affluent $\mathrm{pH}$. The VA/TA ratio varied from 0.08 to 0.49 , and the average VA/TA ratios showed statistical differences (Table 4). The low values of the VA/TA ratios resulted from the high levels of alkalinity in the system, resulting from limestone dissolution and $\mathrm{Ca}^{2+}$ and $\mathrm{Mg}^{2+}$ release. The $\mathrm{pH}$ and VA/TA results in this trial are similar to those obtained by other authors. Ribas (2003) observed pH values of 5.98 and 7.70 in the effluent of a methanogen reactor fed with cassava flour wastewater, which was previously stabilized with dolomitic limestone during the acidogenic phase. Oliveira (2007) obtained average $\mathrm{pH}$ of 6.58 in effluents of anaerobic reactor used for cassava flour wastewater treatment containing dolomitic limestone. That authors indicate that VA/TA values bigger than 0.5 resulted in the instability of the treatment systems, as shown in acidogenic reactor (1.25), methanogenic reactor (0.96 and 1.05) (Ribas, 2003) and single-phase reactor (between 0.56 and 0.82) (Oliveira, 2007). In this trial, $\mathrm{pH}$ and VA/TA ratio results indicated that the anaerobic system remained stable.

Table 5: Impact of organic loading rate (OLR) on partial alkalinity (PA), intermediate alkalinity (IA), total alkalinity (TA) and volatile acidity (VA) and their averages after treatment of cassava wastewater in an anaerobic reactor containing dolomitic limestone

\begin{tabular}{|c|c|c|c|c|}
\hline OLR $\left(\right.$ gDQO L L $\left.^{-1} \mathbf{d}^{-1}\right)$ & $\mathrm{PA}\left(\mathrm{mg} \mathrm{CaCO}_{3} \mathrm{~L}^{-1}\right)$ & $\mathrm{IA}\left(\mathrm{mg} \mathrm{CaCO}_{3} \mathrm{~L}^{-1}\right)$ & $\mathrm{TA}\left(\mathrm{mg} \mathrm{CaCO}_{3} \mathrm{~L}^{-1}\right)$ & $\mathrm{VA}\left(\mathrm{mg} \mathrm{CH}_{3} \mathrm{COOH} \mathrm{L}{ }^{-1}\right)$ \\
\hline 1.23 & $438.50 \mathrm{a}$ & $328.75 \mathrm{ab}$ & $767.2 \mathrm{ab}$ & $327.10 \mathrm{ab}$ \\
\hline 1.54 & $731.50 \mathrm{abc}$ & $253.00 \mathrm{a}$ & $984.50 \mathrm{bc}$ & $134.00 \mathrm{ab}$ \\
\hline 1.84 & $710.17 \mathrm{abc}$ & $261.75 \mathrm{a}$ & $971.92 \mathrm{bc}$ & $118.32 \mathrm{ab}$ \\
\hline 2.45 & $693.08 \mathrm{abc}$ & $278.08 \mathrm{ab}$ & $971.17 \mathrm{bc}$ & $90.50 \mathrm{a}$ \\
\hline 3.40 & $710.33 \mathrm{abc}$ & $340.17 \mathrm{ab}$ & $1,050.50 \mathrm{~cd}$ & $80.91 \mathrm{a}$ \\
\hline 4.96 & $653.30 \mathrm{abc}$ & $414.42 \mathrm{ab}$ & $1,067.80 \mathrm{~cd}$ & $235.77 \mathrm{ab}$ \\
\hline 6.01 & $949.00 \mathrm{bc}$ & $316.10 \mathrm{ab}$ & $1,265.50 \mathrm{de}$ & $193.00 \mathrm{ab}$ \\
\hline 8.11 & $1,008.20 \mathrm{c}$ & $425.90 \mathrm{ab}$ & $1,434.10 \mathrm{e}$ & $185.30 \mathrm{ab}$ \\
\hline 10.14 & $894.60 \mathrm{bc}$ & $477.20 \mathrm{~b}$ & $1,371.80 \mathrm{e}$ & $330.60 \mathrm{ab}$ \\
\hline 12.39 & $901.90 \mathrm{bc}$ & $440.20 \mathrm{ab}$ & $1,342.10 \mathrm{e}$ & $384.54 \mathrm{~b}$ \\
\hline 14.79 & $575.80 \mathrm{ab}$ & $364.60 \mathrm{ab}$ & $940.30 \mathrm{abc}$ & $223.60 \mathrm{ab}$ \\
\hline 16.43 & $397.50 \mathrm{a}$ & $338.10 \mathrm{ab}$ & $735.60 \mathrm{a}$ & $355.00 \mathrm{ab}$ \\
\hline
\end{tabular}

Values followed by the same letter in each column are statistically equal at a $95 \%$ confidence level.

Rev. Ceres, Viçosa, v. 65, n.5, p. 388-394, set/out, 2018 
The effluent presented high TA values that varied from 735.60 to $1434.10 \mathrm{mgCaCO}_{3} \mathrm{~L}^{-1}$, and the TA values in the affluent varied from 195.33 to $367.83 \mathrm{mgCaCO}_{3} \mathrm{~L}^{-1}$. The greatest TA values corresponded to organic loading rates with the greatest $\mathrm{Ca}^{2+}$ and $\mathrm{Mg}^{2+}$ concentrations, as shown in Table 2. The VA varied from 80.91 to $384.54 \mathrm{mgCH}_{3} \mathrm{COOH}$ $\mathrm{L}^{-1}$, and the average VA of the effluent was 621.6 $\mathrm{mgCH}_{3} \mathrm{COOHL}^{-1}$.

As shown in Table 5, statistical differences were observed for PA, IA, TA and VA. The greatest TA values corresponded to organic loading rate with the greatest $\mathrm{Ca}^{2+}$ and $\mathrm{Mg}^{2+}$ concentrations. Buffering was inferred to result from the alkalinity derived from the release of $\mathrm{Ca}^{2+}$ and $\mathrm{Mg}^{2+}$ during limestone dissolution. These results

Table 6: Impact of organic loading rate (OLR) on Total COD removal efficiency and Filtered COD removal efficiency after treatment of cassava wastewater in an anaerobic reactor containing dolomitic limestone

\begin{tabular}{|c|c|c|}
\hline $\begin{array}{l}\text { OLR } \\
\left(\text { gDQO L L } \mathbf{d}^{-1}\right)\end{array}$ & $\begin{array}{c}\text { Total COD } \\
\text { removal } \\
\text { efficiency }(\%)\end{array}$ & $\begin{array}{c}\text { Filtered } \\
\text { COD removal } \\
\text { efficiency }(\%)\end{array}$ \\
\hline 1.23 & 84.93 & 95.22 \\
\hline 1.54 & 92.33 & 94.16 \\
\hline 1.84 & 92.40 & 94.69 \\
\hline 2.45 & 94.33 & 97.55 \\
\hline 3.4 & 87.18 & 92.35 \\
\hline 4.96 & 73.34 & 90.00 \\
\hline 6.01 & 86.45 & 96.72 \\
\hline 8.11 & 87.51 & 95.29 \\
\hline 10.14 & 88.26 & 95.45 \\
\hline 12.39 & 85.92 & 96.23 \\
\hline 14.79 & 83.78 & 94.37 \\
\hline 16.43 & 85.86 & 93.14 \\
\hline
\end{tabular}

Note: Variances of the COD removal data did not show homoscedasticity. Thus, it was not possible to perform the ANOVA test and the means comparison test for this parameter. showed that satisfactory TA values can be obtained when using limestone as an alkalizing agent in single-phase reactors. The VA levels were near the recommended range for stable reactors (100 to $300 \mathrm{mgCH}_{3} \mathrm{COOH} \mathrm{L} \mathrm{L}^{-1}$ ) (Chernicharo, 2007) and made it possible to maintain alkalinity without sudden decreases in $\mathrm{pH}$.

The main indication that the starch wastewater treatment in reactor containing dolomitic limestone occurred efficiently is given by the values of organic matter removal (Table 6). Total COD removal and filtered COD removal were approximately $87 \%$ and $95 \%$, respectively. Total COD removal results presented in Table 6 are higher than those reported by other authors who used dolomitic limestone: $53.90 \%$ (Ribas, 2003), 37 to $46 \%$ (Oliveira, 2007) and 61.95\% (Ribas \& Barana, 2003).

Regarding the treatment system stability, it is known that volatile fatty acids accumulation in the anaerobic reactors effluent is indicative that one or more steps of the system are being impaired. This fact reflects an instability condition, although it does not reflect an inherent deficiency in anaerobic digestion (Aquino \& Chernicharo, 2005). Under real operating conditions, the volatile fatty acids concentration ranges from values close to zero to values of $2,000 \mathrm{mg} \mathrm{L}^{-1}$ or higher, which makes it difficult to define the minimum neutralizing agent dosage, with consequent additional cost (Monteggia et al., 1996). In this experiment, the lactic, acetic and propionic acid concentrations in the reactor effluent were showed in Table 7.

The lowest acid concentrations in Table 7 correspond to the lowest VA values shown in Table 5 because acidity decreased as bacteria used organic acids (Leite et al., 2004). The acetic acid concentrations were observed to decrease at organic loading rates equal to or above 10.14 gCOD L ${ }^{1} \mathrm{~d}^{-1}$, which indicated higher organic acid consumption by methanogenic bacteria. These

Table 7: Impact of organic loading rate (OLR) on lactic acid, acetic acid and propionic acid and their averages after treatment of cassava wastewater in an anaerobic reactor containing dolomitic limestone

\begin{tabular}{|c|c|c|c|}
\hline OLR (gDQO L L-1 $\left.d^{-1}\right)$ & Lactic acid (mg L $\left.\mathbf{L}^{-1}\right)$ & Acetic acid $\left(\mathrm{mg} \mathrm{L}^{-1}\right)$ & Propionic acid $\left(\mathrm{mg} \mathrm{L}^{-1}\right)$ \\
\hline 1.23 & $163.80 \mathrm{c}$ & $286.60 \mathrm{c}$ & $138.60 \mathrm{de}$ \\
\hline 1.54 & $117.94 \mathrm{bc}$ & $191.07 \mathrm{ab}$ & $51.75 \mathrm{abc}$ \\
\hline 1.84 & $105.47 \mathrm{~b}$ & $182.88 \mathrm{ab}$ & $50.92 a b c$ \\
\hline 2.45 & $119.38 \mathrm{bc}$ & $190.17 \mathrm{ab}$ & $31.52 \mathrm{ab}$ \\
\hline 3.40 & - & $170.59 \mathrm{a}$ & $30.53 \mathrm{ab}$ \\
\hline 4.96 & $128.19 \mathrm{bc}$ & $269.12 \mathrm{bc}$ & 100.20 bcde \\
\hline 6.01 & $135.70 \mathrm{bc}$ & $268.10 \mathrm{bc}$ & $55.39 \mathrm{abc}$ \\
\hline 8.11 & $131.70 \mathrm{bc}$ & $186.77 \mathrm{ab}$ & - \\
\hline 10.14 & $113.86 \mathrm{~b}$ & $260.16 \mathrm{bc}$ & $150.00 \mathrm{e}$ \\
\hline 12.39 & $135.49 \mathrm{bc}$ & $227.90 \mathrm{abc}$ & $119.80 \mathrm{cde}$ \\
\hline 14.79 & $117.89 \mathrm{bc}$ & $200.30 \mathrm{abc}$ & $74.60 \mathrm{bcd}$ \\
\hline 16.43 & $113.36 \mathrm{~b}$ & $170.70 \mathrm{a}$ & 89.40 bcde \\
\hline
\end{tabular}

Values followed by the same letter in each column are statistically equal at a $95 \%$ confidence level. 
concentrations were not able to consume alkalinity to the point of causing drops in $\mathrm{pH}$. Thus, the anaerobic system was stable during the 134 days of the test.

\section{CONCLUSIONS}

No statistical significant differences of reactor efficiency were observed among the organic loading rates applied to the system, and the $\mathrm{pH}$ and Volatile acidity/ Total alkalinity remained at optimum levels for the metabolic activity of methanogenic archaea.

These observations resulted from the high bicarbonate levels produced in the system, which offset the generation of volatile acidity and was attributed to the presence of calcium and magnesium ions derived from dolomitic limestone dissolution.

Considering the rapid stabilization of the treatment system at each increment of organic loading rate (12 treatments in only 134 days), smaller limestone dose should be evaluated for buffering the cassava processing wastewater.

\section{ACKNOWLEDGEMENTS}

We acknowledge the Universidade do Oeste do Paraná (UNIOESTE), the Programa de Pós-Graduação em Engenharia Agrícola (Graduate School of Agricultural Engineering Program - PGEAGRI), and the Coordenação de Aperfeiçoamento de Pessoal de Nível Superior (Higher Level Personnel Training Coordination - CAPES).

\section{REFERENCES}

APHA, AWWA \& WPCF (2005) Standard Methods for Examination of Water and Wastewater. $20^{\text {th }}$ ed. Washington, American Public Health Association. 1325p.

Aquino SF \& Chernicharo CAL (2005) Acúmulo de ácidos graxos voláteis (AGVs) em reatores anaeróbios sob estresse: causas e estratégias de controle. Engenharia Sanitária e Ambiental, 10:152-161.

Camili EA \& Cabello C (2008) Avaliação do processo de flotação no tratamento da manipueira originada da fabricação de farinha de mandioca. Energia da Agricultura, 23:32-45.

Cassoni V \& Cereda MP (2011) Avaliação do processo de fermentação acética da manipueira. Energia na Agricultura, 26:101113.

Chernicharo CAL (2007) Biological Wastewater Treatment Series: Anaerobic Reactors. $4^{\text {th }}$ ed. Belo Horizonte, ESA and IWA publishing. $184 \mathrm{p}$.

Duarte AS, Silva ÊFF, Rolim MM, Ferreira RFAEL, Malheiros SMM \& Albuquerque FS (2012) Uso de diferentes doses de manipueira na cultura da alface em substituição à adubação mineral. Revista Brasileira de Engenharia Agrícola e Ambiental, 16:262-267.

Kuczman O, Gomes SD, Tavares MHF, Torres DGB \& Alcântara MS (2011) Produção específica de biogás a partir de manipueira em reator de fase única. Engenharia Agrícola, 3:143-149.
Leite VD, Lopes WS, Sousa JT \& Prasad S (2004) Tratamento anaeróbio de resíduos orgânicos com baixa concentração de sólidos. Engenharia Sanitária e Ambiental, 9:280-284.

Monteggia LO, Beal LL \& Luca SJ (1996) Requerimento de alcalinidade em processos biológicos anaeróbios. In: XXV Congreso Interamericano de Ingeniería Sanitaria y Ambiental, México. Anais, AIDIS p. 1-4.

Oliveira KRF (2007) Processos ecotecnológicos no tratamento de efluentes líquidos de fecularia. Dissertação de Mestrado. Universidade Federal do Mato Grosso do Sul, Campo Grande. 111p.

Oliveira Junior VP, Almeida FFP \& Cereda MP (2012) Dolomitic limestone use for stabilization of vinasse in the acidogenic phase of anaerobic digestion. In: $4^{\text {th }}$ International Conference on Engineering for Waste and Biomass Valorisation, Porto. Anais, Mines d'Albi. CD-ROM.

Palma D, Fuess LT, Lima-Model AN, Conceição KZ, Cereda MP, Tavares MHF \& Gomes SD (2018) Using dolomitic limestone to replace conventional alkalinization in the biodigestion of rapid acidification cassava processing wastewater. Journal of Cleaner Production, 172:2942-2953.

Pereira EL, Campos CMM \& Monterani F (2009) Efeitos do pH, acidez e alcalinidade na microbiota de um reator anaeróbio de manta de lodo (UASB) tratando efluentes de suinocultura. Revista Ambi-Água, 4:157-168.

Pinto PHM \& Cabello C (2011) Tratamento de manipueira de fecularia em biodigestor anaeróbio para disposição em corpo receptor, rede pública ou uso em fertirrigação. Energia na Agricultura, 26:127-140.

Ribas MMF (2003) Comparação da estabilização da manipueira com calcário e hidróxido de sódio na fase acidogênica da biodigestão anaeróbia e uso do biofertilizante. Dissertação de Mestrado. Universidade Estadual Paulista "Júlio de Mesquita Filho", Botucatu. 94p.

Ribas MMF \& Barana AC (2003) Start-up adjustment of a plugflow digester for cassava wastewater (manipueira) treatment. Scientia Agricola, 60:223-229.

Ribas MMF \& Cereda MP (2004) Comparação da estabilização da manipueira com calcário e hidróxido de sódio na fase acidogênica da biodigestão anaeróbia. Energia na Agricultura, 19:33-46.

Ribas MMF, Cereda MP \& Villas Bôas RL (2010) Use of Cassava Wastewater Treated Anaerobically with Alkaline Agents as Fertilizer for Maize (Zea mays L.) Brazilian Archieves Biology and Technology, 53:55-62.

Silva MOSA (1977) Análises físico-químicas para o controle das estações de tratamento de esgoto. São Paulo, CETESB. 226p.

Sun L, Wan S, Yu Z, Wang Y \& Wang S (2012) Anaerobic biological treatment of high strength cassava starch wastewater in a new type up-flow multistage anaerobic reactor. Bioresource Technology, 104:280-288. 